\title{
Components of seed yield in 'Pierre' sideoats grama
}

\author{
A. BOE AND J.L. GELLNER
}

\section{Abstract}

Sideoats grama [Bouteloua curtipendula (Michx.) Torr.] is an important component of grass mixtures planted for conservation and forage throughout the Great Plains. Relationships between seed yield and its components were determined for 'Pierre'sideoats grama for 2 years in a field nursery at Brookings, South Dakota. Analyses of variance indicated highly significant $(P<0.01)$ differences between years for seed yield, number of spikes/culm, number of spikelets/spike, seed set, and seed size but not number of reproductive culms. Significant $(P<0.05)$ positive correlations were found between seed yield and number of reproductive culms and seed yield and seed set in both years. The largest direct path coefficients were between number of reproductive culms and seed yield ( 0.62 and 0.68 in 1985 and 1986 , respectively) and seed set and seed yield ( 0.56 and 0.47 in 1985 and 1986, respectively). Selection for increased number of reproductive culms, which can be easily determined visually, and seed set should result in improved seed yield in this germplasm.

Key Words: Bouteloua curtipendula (Michx.) Torr., caryopsis weight, path coefificient analysis, seed set

Sideoats grama [Bouteloua curtipendula (Michx.) Torr.], a native, warm-season bunchgrass widely distributed in native grasslands of the Great Plains (Newell et al. 1962), is regarded as good to excellent forage for livestock and wildlife (Stubbendieck et al. 1982). It grows well in combinations with other warm-season grasses and is an important component of grass mixtures planted for conservation and summer forage on fine-textured upland soils (Newell et al. 1962).

Improved cultivars of native grasses adapted to a diversity of soil, climate, and management practices are needed throughout the Great Plains. These cultivars must be capable of producing substantial yields of high quality seed to be accepted and planted by seed producers. Smika and Newell (1965) studied seed yield component responses of 2 sideoats grama cultivars adapted to the Central Plains to fertilizer and irrigation treatments, but did not determine the interrelationships between seed yield components. Dewey and Lu (1959) were the first to apply the method of path coefficients (Wright 1921) to genetic improvement of seed yield components in forage grasses, but few studies using this method have been conducted on native grasses (Boe and Ross 1983, Wilson et al. 1981).

\footnotetext{
Authors are associate and assistant professor, Plant Science Department, South Dakota State University, Brookings 57007.

Authors wish to thank David George for assistance in data acquisition.

This article is a contribution from the South Dakota Agricultural Experiment Station Journal Series No. 2443.

Manuscript accepted 8 March 1990.
}

The objective of this study was to determine the interrelationships among seed size, seed set, reproductive culm number, and other seed production components and seed yield in 'Pierre' sideoats grama, a cultivar adapted to the northern Great Plains.

\section{Materials and Methods}

In May, 1984, 70 randomly selected seedlings of Pierre sideoats grama were transplanted from the greenhouse to a field nursery on a Vienna loam [fine-loamy, mixed Udic Haploborall] at Brookings, $S$. Dak. The nursery design was 14 rows of 5 plants with $1 \mathrm{~m}$ inter-and intrarow spacings. When caryopses reached hard dough in 1985 and 1986, all inflorescences of individual plants were hand-harvested, placed in paper bags, and air-dried. Data obtained for individual plants in 1985 and 1986 were: (1) number of reproductive culms, (2) total weight of all spikes stripped from rachises, (3) weights of 2 random 25-spike samples, (4) number of spikelets/spike from 2 random 10-spike samples, (5) seed set or number of caryopses/spikelet from each 10-spike sample, (6) number of spikes/reproductive culm (calculated from number of reproductive culms, total weight of spikes, and weights of 225 -spike samples), (7) seed yield (total caryopses weight obtained by threshing spikes on a rub-board and separating caryopses from spikelet bracts with a seed blower), and (8) weights of 2 random 100 caryopses samples (seed size). Due to mortality over the 2-year study, data for both years were obtained for $\mathbf{5 8}$ of the $\mathbf{7 0}$ original transplants.

Analyses of variance were used to partition the variation in seed yield and its components into year, plant, and year by plant interaction effects. The year by plant interaction effect was the error term and used to test significance of the year and plant effects. Simple linear correlation coefficients for all possible comparisons were also calculated for each year. Path coefficients (Dewey and Lu 1959) were computed from partial regression coefficients ( $\mathrm{Li}$ 1975) for components of seed yield per plant. Path coefficients quantify direct and indirect effects of interrelated components of seed yield.

\section{Results and Discussion}

Highly significant $(P<0.01)$ differences were found between years for seed yield and all components other than number of reproductive culms (Table 1). These data demonstrated, as was found for blue grama [Bouteloua gracilis (H.B.K.) Log. ex Steud.] (Wilson et al. 1981), the strong influence of environmental differences between years on seed yield components in sideoats grama.

Highly significant $(P<0.01)$ positive simple linear correlations were found between number of reproductive culms and seed yield in 1985 and $1986(r=0.80$ and 0.83 , respectively) (Table 2). Smika 
Table 1. Annual seed yield and component means for 'Pierre' sideoats grama space-plants evaluated at Brookings, South Dakota.

\begin{tabular}{|c|c|c|c|c|c|c|}
\hline Year & $\begin{array}{c}\text { Culms/ } \\
\text { plant }\end{array}$ & $\begin{array}{l}\text { Spikes/ } \\
\text { culm }\end{array}$ & $\begin{array}{l}\text { Spikelets/ } \\
\text { spike }\end{array}$ & $\begin{array}{l}\text { Seed } \\
\text { size }\end{array}$ & $\begin{array}{c}\text { Seed } \\
\text { set }\end{array}$ & $\begin{array}{l}\text { Seed } \\
\text { yield }\end{array}$ \\
\hline & $\ldots$ & - -no. - & $\ldots$ & $-\mathrm{mg}-$ & $-\%$ & $-g-$ \\
\hline $\begin{array}{l}1985 \\
1986\end{array}$ & $\begin{array}{l}176.1 \\
187.1\end{array}$ & $\begin{array}{l}21.0 \\
25.9\end{array}$ & $\begin{array}{l}8.6 \\
6.2\end{array}$ & $\begin{array}{l}82.9 \\
85.7\end{array}$ & $\begin{array}{l}32.0 \\
25.0\end{array}$ & $\begin{array}{l}8.3 \\
6.4\end{array}$ \\
\hline $\begin{array}{l}\text { Sign. } \\
\text { Level }\end{array}$ & NS & $* *$ & $* *$ & $* *$ & ** & $* *$ \\
\hline
\end{tabular}

NS, * Annual means not significant or significantly different at the 0.01 level, respectively.

and Newell (1965) found inflorescence number per meter of row strongly correlated with seed yields of 'Butte' and 'Trailway' sideoats grama at 2 Nebraska locations over a 3-year period.

Significant $(P<0.05)$ positive correlations were also found between seed set and seed yield in 1985 and 1986 (Table 2). Numbers of spikes/culm and spikelets/spike were significantly $(P<0.05)$ correlated with seed yield in 1 of the 2 years. The only significant negative correlations found in this study were between number of spikes/culm and seed size in 1985 and 1986 and number of spikes/culm and seed set in 1985 and 1986.

Path coefficient analysis indicated that number of reproductive culms had the strongest direct effect on seed yield (Table 2). Similar results have been reported for crested wheatgrass (Agropyron cristatum L.) (Dewey and Lu 1959) and big bluestem (Andropogon gerardii Vitman) (Boe and Ross 1983). Small positive indirect

Table 2. Correlation and path coefficient analyses of seed yield components in a space-plant nursery of 'Pierre' sideoats grama.

\begin{tabular}{|c|c|c|}
\hline \multirow[b]{2}{*}{ Pathways of Association } & \multicolumn{2}{|c|}{ Coefficients } \\
\hline & 1985 & 1986 \\
\hline $\begin{array}{l}\text { Seed yield vs. reproductive culms } \\
\text { Direct effect } \\
\text { Indirect effect via spikes/culm } \\
\text { Indirect effect via spikelets/spike } \\
\text { Indirect effect via seed set } \\
\text { Indirect effect via seed size }\end{array}$ & 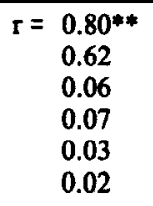 & $\begin{array}{l}0.83^{* *} \\
0.68 \\
0.06 \\
0.04 \\
0.04 \\
0.02\end{array}$ \\
\hline $\begin{array}{l}\text { Seed yield vs. spikes/culm } \\
\text { Direct effect } \\
\text { Indirect effect via reproductive culms } \\
\text { Indirect effect via spikelets/spike } \\
\text { Indirect effect via seed set } \\
\text { Indirect effect via seed size }\end{array}$ & $\begin{array}{r}r=0.23 \\
0.39 \\
0.10 \\
-0.04 \\
-0.18 \\
0.04\end{array}$ & $\begin{array}{l}0.32 * \\
0.43 \\
0.10 \\
0.04 \\
-0.20 \\
-0.04\end{array}$ \\
\hline $\begin{array}{l}\text { Seed yield vs. spikelets/spike } \\
\text { Direct effect } \\
\text { Indirect effect via reproductive culms } \\
\text { Indirect effect via spikes/culms } \\
\text { Indirect effect via seed set } \\
\text { Indirect effect via seed size }\end{array}$ & 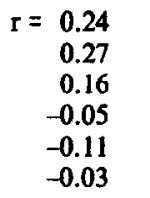 & $\begin{array}{l}0.32^{*} \\
0.20 \\
0.14 \\
0.08 \\
-0.09 \\
-0.01\end{array}$ \\
\hline $\begin{array}{l}\text { Seed yield vs. seed set } \\
\text { Direct effect } \\
\text { Indirect effect via reproductive culms } \\
\text { Indirect effect via spikes/culm } \\
\text { Indirect effect via spikelets/spike } \\
\text { Indirect effect via seed size }\end{array}$ & $r=0.47^{* *}$ & $\begin{array}{r}0.33^{*} \\
0.47 \\
0.05 \\
-0.18 \\
-0.04 \\
0.03\end{array}$ \\
\hline $\begin{array}{l}\text { Seed yield vs. seed size } \\
\text { Direct effect } \\
\text { Indirect effect via reproductive culms } \\
\text { Indirect effect via spikes/culm } \\
\text { Indirect effect via spikelets/spike } \\
\text { Indirect effect via seed set }\end{array}$ & $\begin{array}{r}0.27 \\
0.17 \\
0.06 \\
-0.10 \\
-0.04 \\
0.18\end{array}$ & $\begin{array}{r}0.21 \\
0.15 \\
0.09 \\
-0.12 \\
-0.01 \\
0.10\end{array}$ \\
\hline Coefficient of determination & 0.96 & 0.95 \\
\hline
\end{tabular}

*,**C Correlation coefficients significantly different from 0 at the 0.05 and 0.01 levels, respectively.

The yield component model was significant at the 0.01 level in both years. influences of the 4 other components contributed to the large total correlations between seed yield and reproductive culms in both years.

Although significant $(P<0.05)$ total correlations were found between seed yield and seed set in both years, indirect negative effects of numbers of spikes/culm and spikelets/spike masked the direct influence of seed set on seed yield (Table 2). Similarly, when calculated on a per culm basis, Wilson et al. (1981) reported strong negative correlations between numbers of spikes and spikelets per spike and fertility (seed set) in blue grama in Colorado.

The direct effect of number of spikes/culm was larger than the direct effects of number of spikelets/spike and seed size (Table 2). Although linear correlations between these 3 components and seed yield were similar, the stronger negative indirect influence of seed set on spikes/culm masked its relatively stronger direct effect. Positive indirect effects that contributed to total correlations between number of spikelets/spike and seed yield and seed size and seed yield were number of reproductive culms and seed set, respectively.

Encouraging findings of this study, elucidated by path coefficient analysis, were absences of negative correlations between seed size, number of reproductive culms, and seed set. This indicates that selection for seed yield in this germplasm would not adversely affect seed size, which is the primary factor influencing seedling vigor in forage grasses (Kneebone and Cremer 1955). Wilson et al. (1981) found no correlation between reproductive culms/plant and seed size and a small negative correlation between fertility and seed size in blue grama. They suggested that in grasses that produce small caryopses, seed development may not be limited by the amount of photosynthetic products even when fertility percentage is high. In crested wheatgrass, fertility was strongly negatively associated with seed size (Dewey and Lu 1959). However, fertility in their study was determined as seeds per spikelet with no indication that the actual number of florets per spikelet was determined.

This study suggests that number of reproductive culms and seed set had strong direct influences on seed yield and should be given primary attention in a breeding program aimed at increasing seed yield. Harlan (1950) found fixation for numerous reproductive culms much easier to achieve than fixation for abundant leaf production in sideoats grama germplasm from the southern Great Plains. Number of reproductive culms can be quickly evaluated visually in a space-plant nursery, thus large populations could be screened for this trait in a short period of time. Seed set would be difficult to assess in the field and thus would be more efficiently evaluated after selection for number of reproductive culms.

\section{References}

Boe, A., and J.G. Ross. 1983. Path coefficient analysis of seed yield in big bluestem. J. Range Manage. 36:652-653.

Dewey, D.R., and K.H. Lu. 1959. A correlation and path-coefficient analysis of components of crested wheatgrass seed production. Agron. J. 51:515-518.

Harlan, J.R. 1950. The breeding behavior of sideoats grama in partially isolated populations. Agron. J. 42;20-24.

Kneebone, W.R., and C.L. Cremer. 1955. The relationship of seed size to seedling vigor in some native grass species. Agron. J, 47:472-477.

Li, C.C. 1975. Path analysis: A primer. Boxwood Press. Pacific Grove, Calif.

Newell, L.C., R.D.Staten, E.B. Jackson, and E.C. Conard. 1962. Sideoats grama in the central Great Plains. Nebr. Agr. Exp. Sta. Res. Bull. 207.

Smikn, D.E., and L.C. Newell. 1965. Irrigation and fertilization practices for seed production from established stands of sideoats grama. Neb. Agr. Exp. Sta. Res. Bull. 218.

Stubbendieck, J., S.L. Hatch, and K.J. KJar. 1982. North American range plants. 2nd ed. Univ. Neb. Press, Lincoln.

Wilson, A.M., R.L. Cuany, J.G. Fraser, and W.R. Oaks. 1981. Relationships among components of seed yield in blue grama. Agron. J. 73:1058-1062.

Wright, S. 1921. Correlation and causation. J. Agr. Res. 20:557-585. 